\title{
PEMBANGUNAN APLIKASI UJIAN ONLINE MENGGUNAKAN AKSES TOKEN \& ALGORITMA SIMPLE RANDOM SAMPLING
}

\author{
Erwin Yulianto ${ }^{1}$, Firman Sanjaya ${ }^{2}$, Trisno Setiadi ${ }^{3}$ \\ ${ }^{1,3}$ Universitas Langlangbuana, ${ }^{2}$ Universitas Pasundan \\ 1eyulianto@unla.ac.id, ${ }^{2}$ firmanpizz@unpas.ac.id, ${ }^{3}$ trisnagdrgn@gmail.com
}

\begin{abstract}
ABSTRAK
Salah satu tujuan yang dicanangkan oleh pihak sekolah yaitu untuk melakukan pengukuran pengetahuan dan kecerdasan para siswanya melalui ujian yang dilakukan secara berkala. Salah satu cara untuk mewujudkannya adalah dengan memiliki sistem ujian dan penilaian yang baik. Kendala yang dialami di banyak sekolah yaitu terkait dengan pelaksanaan ujian yang masih menggunakan metode manual dan paper based (belum terkomputerisasi). Oleh karena itu dilakukan pengembangan sistem informasi berbasis web berupa sistem ujian online dengan algoritma simple random sampling dengan fitur pertanyaan acak dan akses token. Metodologi Penelitian yang diterapkan yaitu metode penelitian \& pengembangan, sementara model pengembangan sistem yang digunakan menggunakan model evolutionary prototype. Aplikasi Ujian Online dengan menggunakan akses token \& algoritma Simple Random Sampling dilengkapi dengan fitur akses token, acak jawaban, acak soal dan otomatis menampilkan nilai pada setiap siswa untuk meminimalisasi kecurangan siswa dalam mengerjakan soal-soal ujian / ulangan. Dengan adanya aplikasi dimaksud, permasalahan di sekolah yang dalam hal proses pelaksanaan ujian yang masih menggunakan proses manual baik ujian sekolah maupun ulangan harian menjadi berbasis komputerisasi untuk memudahkan guru maupun siswa dalam proses pembelajaran yang efektif sehingga dapat meningkatkan hasil evaluasi atas kualitas belajar siswa.
\end{abstract}

Kata Kunci : ujian daring, akses token, algoritma simple random sampling.

\begin{abstract}
One of the goals proclaimed by the school is to measure the knowledge and intelligence of students through periodic exams. One way to make this happen is to have a good examination and assessment system. The obstacles experienced in many schools are related to the implementation of exams that still use manual and paper based methods (not computerized). Therefore, the development of a web-based information system in the form of an online examination system with a simple random sampling algorithm with random questions and token access features. The research methodology applied is the research \& development method, while the system development model used uses the evolutionary prototype model. The Online Exam application uses token access \& the Simple Random Sampling algorithm is equipped with token access features, random answers, random questions and automatically displays the value for each student to minimize student cheating in working on exam questions / tests. With the existence of the intended application, problems in schools which are in the process of implementing exams that still use manual processes, both school exams and daily tests, become computerized to facilitate teachers and students in an effective learning process so as to improve the results of evaluating the quality of student learning
\end{abstract}

Keywords: online exam, token access, simple random sampling algorithm.

\section{PENDAHULUAN}

Bidang pendidikan perlu mendapat perhatian yang lebih karena menjadi sebuah aspek yang penting dalam kehidupan bagi sumber daya manusia. Pendidikan menentukan bagaimana pola pikir manusia tersebut untuk maju. Seperti yang dikemukakan oleh 
Sukmadinata (2003) bahwa proses pendidikan terarah pada peningkatan penguasaan pengetahuan, kemampuan ketrampilan, pengembangan sikap dan nilai-nilai dalam rangka pembentukan dan pengembangan diri peserta didik. Pemerintah harus lebih memperhatikan bidang pendidikan. Salah satu caranya adalah dengan menyediakan sarana yang menunjang suatu sekolah agar lebih optimal. Dengan perkembangan teknologi yang semakin pesat, sarana dan prasarana pendidikan pun harus mengikutinya, salah satunya dengan media komputerisasi dan internet. Dengan internet, siswa maupun guru dapat mengakses ilmu pengetahuan dan informasi kapan saja dan dimana saja.

Banyak sekolah yang saat ini masih melaksanakan proses belajar mengajar dengan berbasis kertas (paper based). Dalam pelaksaan ujian pun, baik ujian sekolah maupun ulangan harian masih menggunakan lembar jawaban yang bersifat tertulis serta belum berbasis komputerisasi. Dalam bidang pendidikan, kemudahan pelaksanaan ujian dan hasil yang optimal menjadi prioritas yang harus selalu diutamakan. Oleh karena itu, di era transformasi digital, diperlukan perubahan pelaksanaan dari ujian berbasis kertas menjadi ujian berbasis online. Selain faktor biaya, kualitas suatu sekolah adalah tujuan orang tua murid memilih tempat yang tepat untuk menyekolahkan anak-anaknya. Untuk mendapatkan hasil yang optimal dalam proses pengembangan dibutuhkan waktu yang tidak sedikit. Salah satu cara yang digunakan yaitu melakukan digitalisasi pada sekolah khususnya di dalam sistem pembelajaran untuk lebih memudahkan siswa maupun guru.

Ujian Berbasis Komputer disebut juga Computer Based Test (CBT) adalah sistem pelaksanaan ujian dengan menggunakan komputer sebagai media ujiannya. Dalam pelaksanaannya, Ujian Berbasis Komputer berbeda dengan sistem ujian berbasis kertas atau Paper Based Test (PBT) yang selama ini sudah berjalan. Hasil penyelenggaraan Ujian Berbasis Komputer pada sekolah cukup menggembirakan dan semakin mendorong untuk meningkatkan literasi siswa terhadap Teknologi Informasi dan Komunikasi (Kemdikbud, 2019). Sayangnya, pelaksanaan ujian berbasis komputer baru dilaksanakan pada ujian negara, sementara pada pelaksanaan ujian sekolah untuk mengukur dan mengevaluasi hasil pembelajaran siswa masih berbasis kertas sehingga perlu dikembangkan aplikasi serupa. Ujian sekolah bisa dilaksanakan secara berkala untuk digunakan sebagai pengukuran daya tangkap siswa terhadap materi ajar.

Dengan adanya teknologi komputer yang menunjang pembelajaran maka akan membantu suatu sistem sekolah berjalan dengan baik. Pembangunan aplikasi ujian berbasis web merupakan solusi yang tepat dalam memecahkan masalah tersebut karena aplikasi ini 
akan sangat memudahkan siswa dan guru dalam melakukan pelaksaan ujian maupun latihan ujian dimanapun. Untuk itu diperlukan sebuah perancangan pembuatan aplikasi ujian sekolah online berbasis web agar siswa dan guru dapat lebih efektif serta efisien dalam melaksanakan ujian sekolah atau ulangan harian ujian dan mengurangi adanya peluang siswa untuk melakukan kecurangan pada saat mengerjakan soal serta dapat melaksanakan latihan ujian dimanapun. Pada penelitian ini akan dibuat sebuah aplikasi ujian sekolah online berbasis web dengan sistem akses token dan pemanfaatan algoritma simple random sampling untuk mengeluarkan soal secara acak kepada siswa.

\section{Perumusan Masalah}

Berdasarkan latar belakang yang telah diuraikan sebelumnya, maka penulis merumuskan masalah penelitian yang akan dilakukan yaitu :

1. Bagaimana melakukan transformasi digital pada sistem pelaksanaan ujian sekolah yang saat ini masih menggunakan proses ujian berbasis kertas (paper based) ?

2. Bagaimana memitigasi adanya peluang siswa untuk melakukan kecurangan pada saat mengerjakan soal ujian?

3. Bagaimana melakukan evaluasi pelaksanaan ujian sekolah yang efektif dan efisien?

\section{Tujuan Penelitian}

Tujuan yang ingin dicapai di dalam penelitian ini antara lain :

1. Mengembangkan aplikasi ujian online dengan fitur penilaian otomatis dalam proses pelaksanaan ujian di sekolah.

2. Menerapkan aplikasi ujian online dengan menggunakan fitur akses token dan algoritma Simple Random Sampling dalam proses pelaksanaan ujian di sekolah.

3. Membuat laporan dan dashboard pada aplikasi ujian sekolah online sebagai bahan evaluasi bagi guru dan siswa dalam proses belajar mengajar.

\section{METODE PENELITIAN}

Penelitian yang dilakukan memakai metode pengembangan sementara untuk model pengembangan sistem menggunakan model evolutionary prototyping. Menurut Sugiyono dalam bukunya, metode pengembangan adalah metode penelitian yang digunakan untuk menghasilkan produk tertentu dan menguji keefektifan produk tersebut. Model pengembangan sistem yang digunakan adalah model Evolutionary Prototyping yang merupakan salah satu model pengembangan perangkat lunak evolusioner yang dibuat dengan mengkombinasikan prototype dengan iterasi proses (Boehm, 1988). Dengan model 
Evolutionary Prototyping ini pengembang dan pelanggan dapat saling berinteraksi selama proses pembuatan sistem (Awad, 2005).

Dengan model ini, sepanjang seluruh proyek, pelanggan selalu diminta untuk memberikan umpan balik untuk setiap prototype yang dibuat. Ini untuk memastikan fungsionalitas berdasarkan pada persyaratan yang dicari pelanggan dalam suatu produk atau layanan. Segera setelah proyek hampir selesai, prototipe harus sudah dikalibrasi dengan baik dengan persyaratan dan kebutuhan pasar sasarannya. Model Evolutioner Prototyping dapat dilihat pada Gambar 1 berikut.

\section{Evolutionary prototyping}

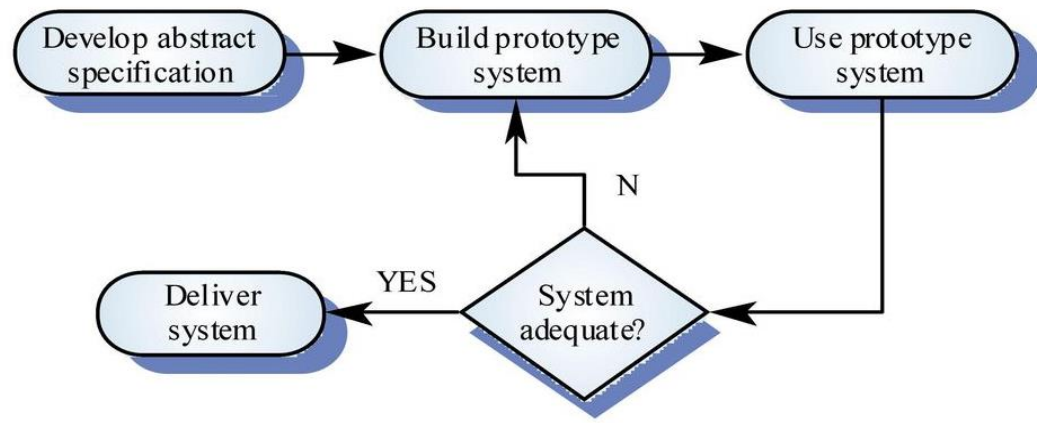

Gambar 1. Model EvolutionerPrototype

(Sumber : Sommerville, 2004)

Aktivitas-aktivitas yang dilakukan oleh peneliti dengan mengacu pada model Evolutionary Prototyping, antara lain :

1. Develop abstract specification, pada tahap ini dilakukan pengumpulan kebutuhan, developer dan pertemuan dengan user serta menentukan tujuan umum kebutuhan dengan pihak sekolah yang diketahui dan gambaran bagian-bagian yang akan dibutuhkan berikutnya dari sistem dengan cara mendengar keluhan dari sekolahsekolah untuk membuat suatu sistem yang sesuai kebutuhan.

2. Build prototype system, pada tahap ini dilakukan perancangan dan pembuatan prototype sistem, prototype yang dibuat disesuaikan dengan kebutuhan sistem yang telah didefinisikan sebelumnya dari keluhan pelanggan atau pengguna.

3. Use prototype system, pada tahap ini prototype dari sistem di uji coba oleh pihak sekolah, kemudian dilakukan evaluasi kekurangan-kekurangan dari kebutuhan pihak 
sekolah. Pengembangan kembali dilakukan setelah mendengarkan keluhan dari pelanggan untuk memperbaiki prototype yang ada.

4. System adequate, pada tahap ini sistem dievaluasi oleh pihak sekolah terkait kesesuaian fungsional aplikasi dengan yang diharapkan oleh pihak Sekolah. Jika telah sesuai maka akan dilanjutkan ke tahapan system delivery, jika tidak maka akan kembali dilakukan build prototype system.

5. System Delivery, pada tahap ini sistem sudah sesuai dengan yang diharapkan oleh pihak pengguna dan sistem telah siap digunakan oleh sekolah untuk melakukan ujian secara online dan mencetak kartu ujian.

\section{HASIL DAN PEMBAHASAN}

\section{Analisis Proses Bisnis}

Analisis proses bisnis dilakukan untuk mendefiniskan kebutuhan untuk melakukan rekayasa proses bisnis, untuk lebih menjelaskan hubungan antara analisa proses bisnis dengan rekayasa ulang proses bisnis.

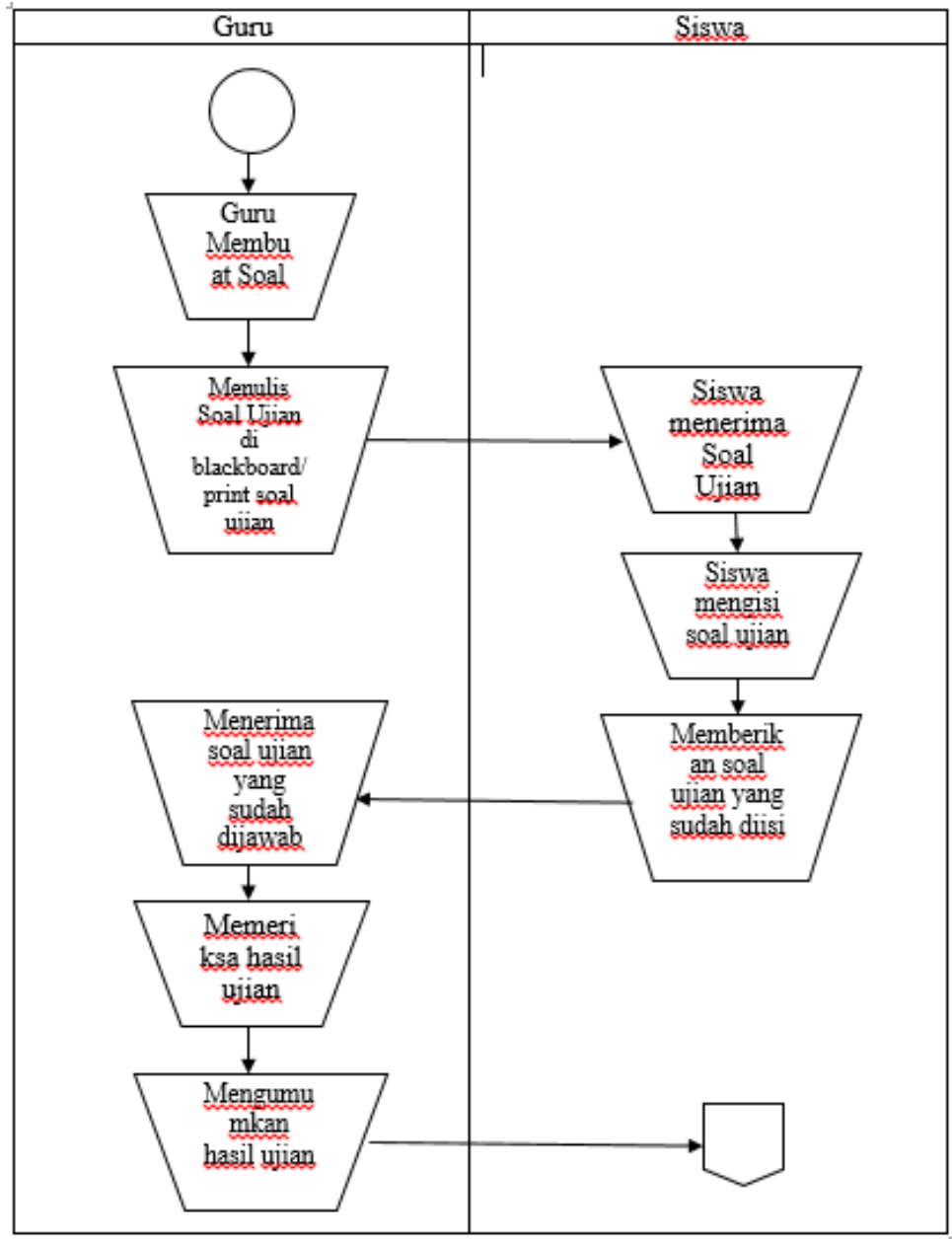

Gambar 2. Proses Bisnis Yang Berjalan 
Proses bisnis saat ini masih menggunakan sistem ujian tertulis menggunakan kertas (Paper Based Test). Penyelenggara harus menyediakan lebih banyak ATK seperti kertas dan mencetak soal ujian yang tentunya memakan biaya dan waktu yang tidak sedikit, serta masih bisa terjadi kemungkinan terdapatnya gangguan teknis berupa keterlambatan soal dan ketidakjelasan hasil cetak soal. Adapun proses bisnis yang sedang berjalan pada sistem ujian di sekolah-sekolah saat ini dapat dilihat pada Gambar 2 diatas.

Proses bisnis yang diusulkan adalah sistem ujian berbasis komputer (Computer Based Test). Dengan mengimplementasikan Akses Token untuk masuk ke dalam ujian dan metode simple random sampling untuk mengurangi tingkat kecurangan dalam mengerjakan soal karena soal ujian akan muncul secara acal dan otomatis. Proses bisnis yang diusulkan dapat dilihat pada Gambar 3 berikut.

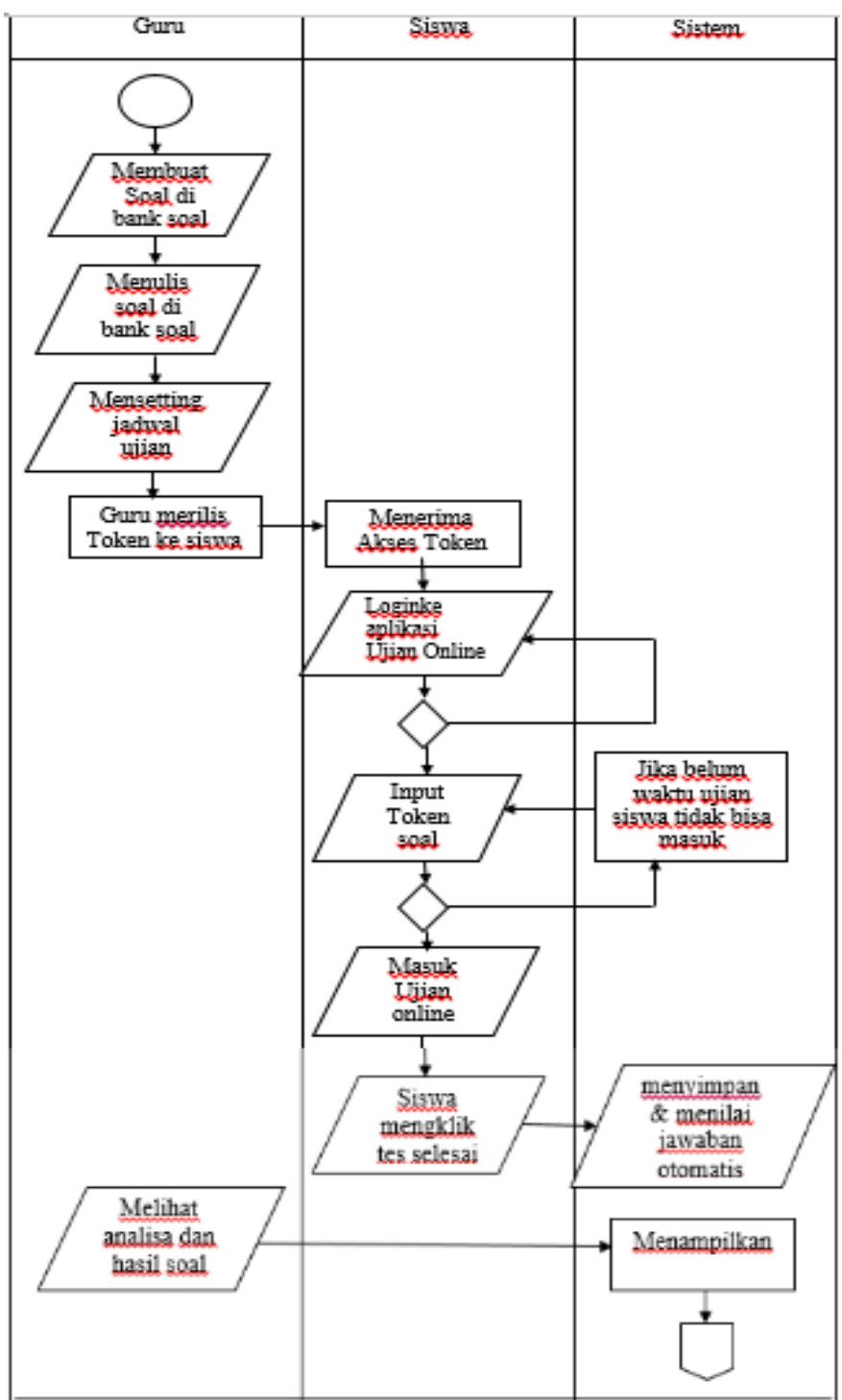

Gambar 3. Proses Bisnis Yang Diharapkan 


\section{Penerapan Ujian Online (Computer Based Test)}

Jenis - jenis ujian berdasarkan bentuknya terbagi menjadi dua yaitu ujian tulis dan ujian lisan. Kedua jenis ujian tersebut dapat dilaksanakan menggunakan alat bantu komputer atau dikenal sebagai Ujian Berbasis Komputer (Computer Based Test / CBT) sebagaimana dilihat pada Gambar 4 berikut.

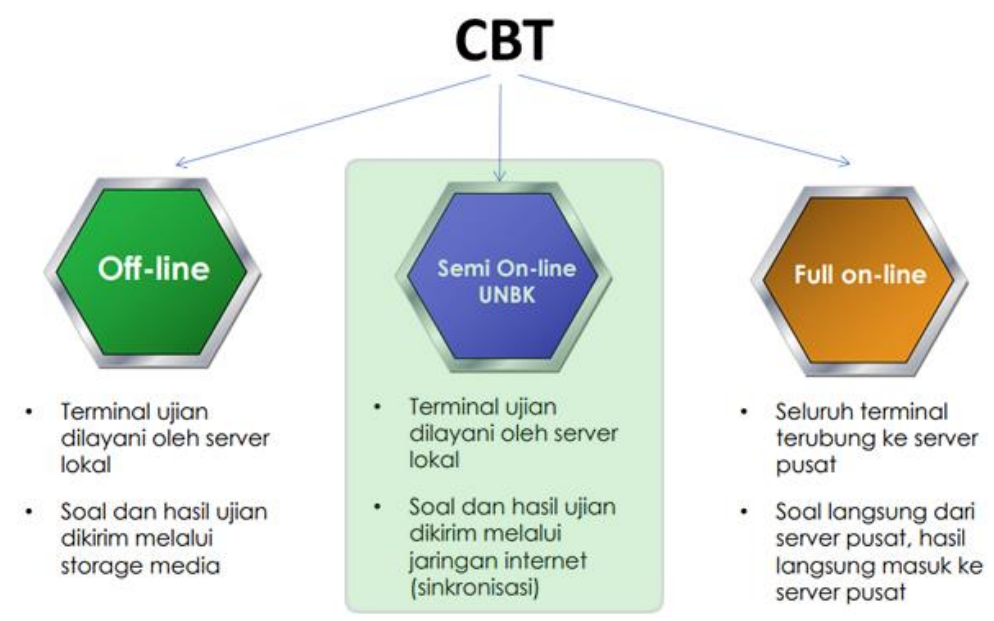

Gambar 4. Konsep Ujian Berbasis Komputer

(Sumber : Kemdikbud, 2019)

Pelaksanaan ujian dengan menggunakan komputer dilakukan di dalam sebuah jaringan baik itu jaringan intranet maupun internet sehingga dapat tergolong sebagai ujian online. Ujian online adalah suatu evaluasi yang dilaksanakan secara serentak dengan menggunakan jaringan internet/intranet. Ujian online dapat dilaksanakan apabila suatu sekolah atau instansi tersebut memiliki fasilitas yang memadai. Sekolah - sekolah biasanya melaksanakan ujian online untuk pelaksanaan Ujian Sekolah atau Ujian Akhir Semester. Ujian Sekolah dilakukan untuk mengukur pencapaian kompetensi peserta didik sebagai pengakuan prestasi belajar atau penyelesaian dari Sekolah. Dalam ujian sekolah, tes hasil belajar dapat digolongkan ke dalam dua jenis, antara lain (Ngalimun, 2017) :

1. Tes essay, terbagi menjadi dua yaitu essay bentuk bebas dan essay bentuk terbatas,

2. Tes Obyektif, terbagi menjadi lima jenis yaitu :
a. True-False test
b. Matching test,
c. Completion test
d. Fill in test
e. Multiple Choice item test. 
Media-media yang dipakai atau digunakan untuk menerapkan ujian online, contohnya seperti internet, intranet, komputer, dan aplikasi pendukung lainnya. Selain itu ada juga tahapan untuk menerapkan ujian online adalah setiap komputer client harus terhubung ke server, aplikasi pendukung ujian harus terinstal ke semua komputer client (Rusmawan, 2017).

\section{Perancangan Berorientasi Objek}

Perancangan sistem yang akan digunakan menggunakan pendekatan perancangan berorientasi objek dengan menggunakan Diagram UML sebagai standarisasi internasional. Use Case Diagram

Use case diagram pada aplikasi Ujian Online Menggunakan Akses Token \& Algoritma Simple Random Sampling (Computer Based Test) mendeskripsikan interaksi antara aktor dengan sistem yang akan dibuat, diantaranya :

1. Admin, merupakan administrator server yang berhak melakukan pengelolaan data sekolah, daftar kelas, daftar siswa, mata pelajaran, bank soal, cetak kartu ujian, hasil dan analisa soal.

2. Guru, merupakan pengguna dengan akses yaitu kelola bank soal, analisa soal dan hasil. Use Case Diagram dari aplikasi Ujian Online Menggunakan Akses Token \& Algoritma Simple Random Sampling (Computer Based Test) dapat dilihat pada Gambar 5 sebagai berikut.

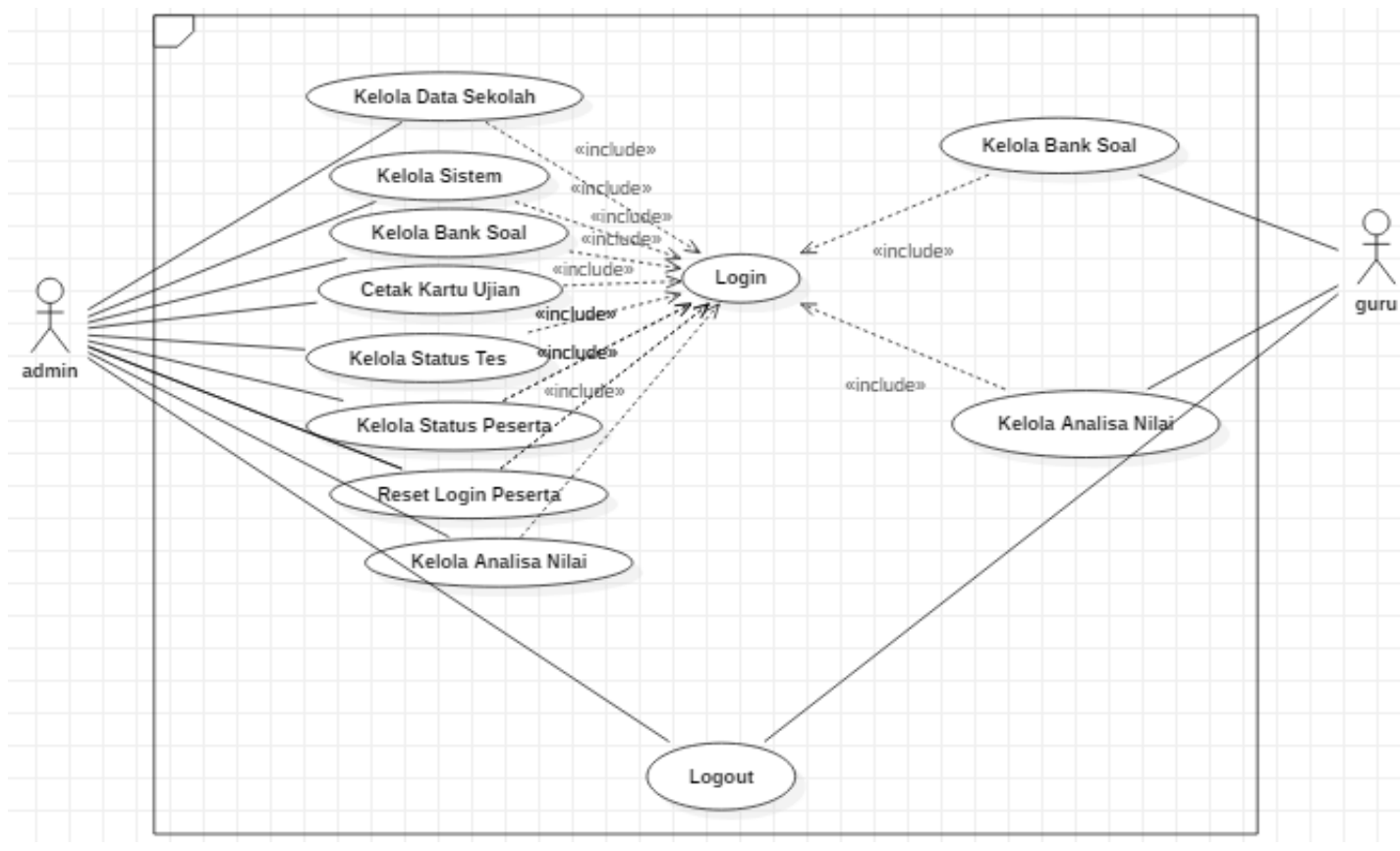

Gambar 5. Use Case Diagram 


\section{Class Diagram}

Perancangan Class diagram yang akan menjadi panduan dalam membuat perancangan antar muka dan perancangan basis data pada aplikasi Ujian Online Menggunakan Akses Token \& Algoritma Simple Random Sampling (Computer Based Test) dapat dilihat pada Gambar 6 sebagai berikut.

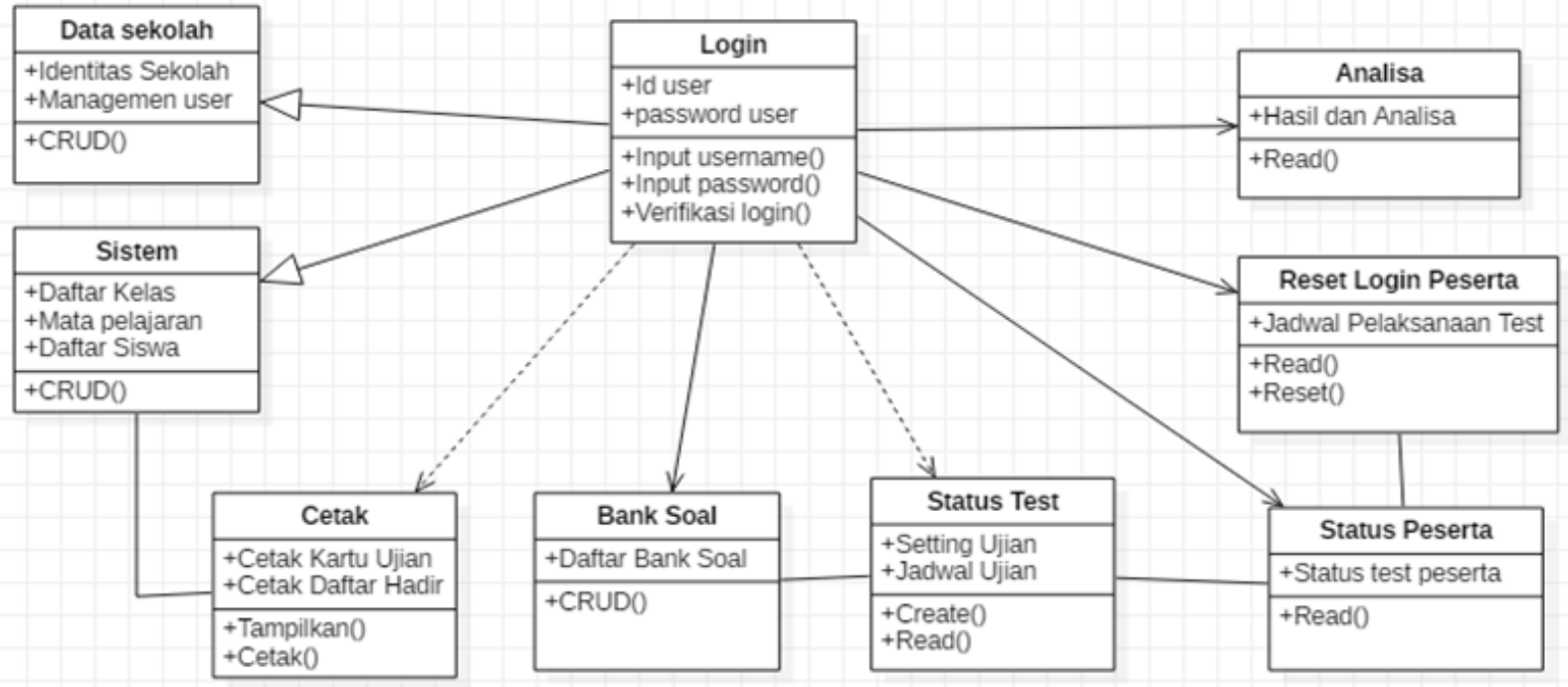

Gambar 6. Class Diagram

\section{Perancangan Basis Data}

Aplikasi Ujian Online Menggunakan Akses Token \& Algoritma Simple Random Sampling yang dikembangkan terdiri dari beberapa tabel. Tabel-tabel tersebut memiliki struktur tabel yang saling berkaitan dan memberikan informasi yang lengkap bagi pengguna sistem dengan Primary Key (PK) dan Foreign Key (FK) yang saling terkait. Berikut Tabel 1 struktur tabel dari Aplikasi Ujian Online yang dikembangkan.

Tabel 1. Struktur Tabel

\begin{tabular}{|c|c|c|}
\hline No & $\begin{array}{l}\text { Nama } \\
\text { Tabel }\end{array}$ & Field-Field \\
\hline 1 & $\begin{array}{l}\text { Tabel } \\
\text { cbt_ujian }\end{array}$ & 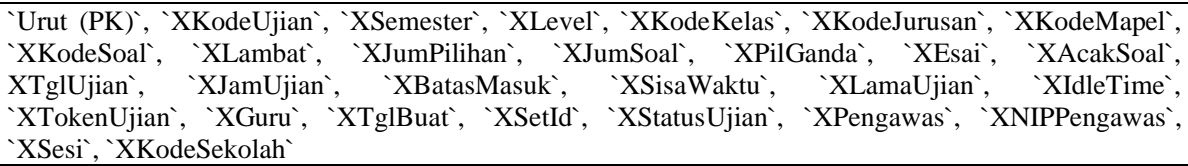 \\
\hline 2 & $\begin{array}{l}\text { Tabel } \\
\text { cbt_jawaban }\end{array}$ & 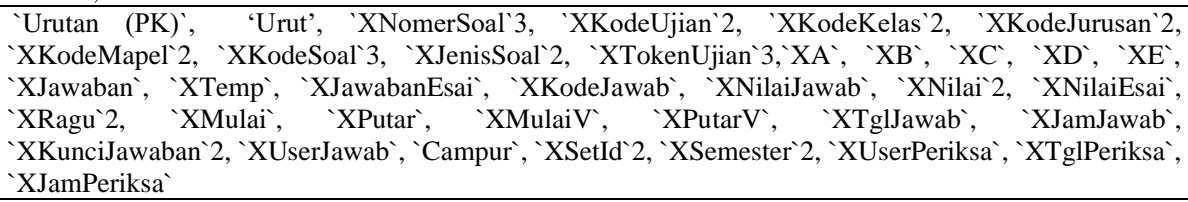 \\
\hline 3 & $\begin{array}{l}\text { Tabel } \\
\text { cbt_paketsoal }\end{array}$ & 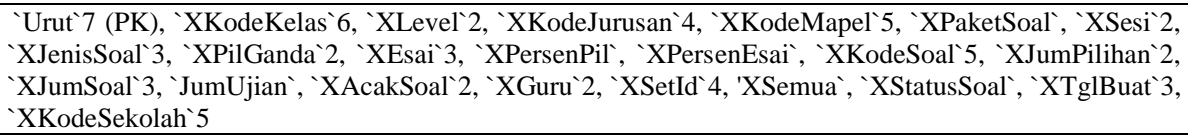 \\
\hline 4 & $\begin{array}{l}\text { Tabel } \\
\text { cbt_soal }\end{array}$ & 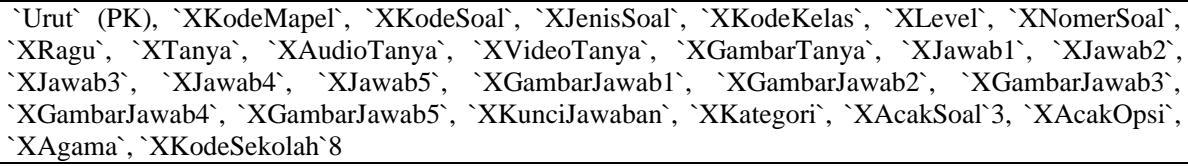 \\
\hline
\end{tabular}




\begin{tabular}{|c|c|c|}
\hline 5 & $\begin{array}{l}\text { Tabel } \\
\text { cbt_admin }\end{array}$ & 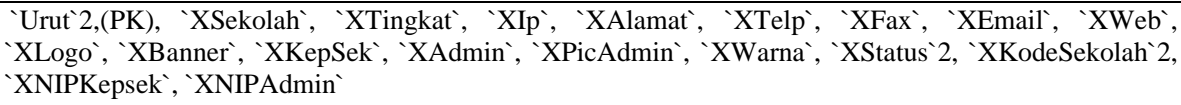 \\
\hline 6 & $\begin{array}{l}\text { Tabel } \\
\text { cbt_nilai }\end{array}$ & 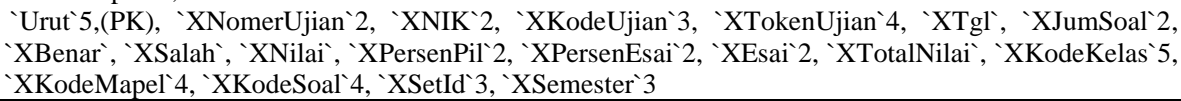 \\
\hline 7 & $\begin{array}{l}\text { Tabel } \\
\text { cbt_siswa }\end{array}$ & 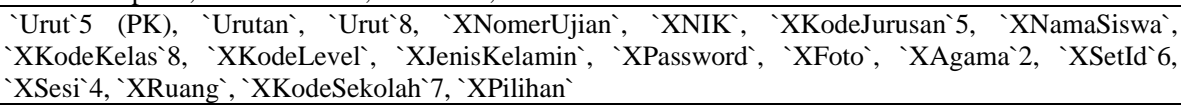 \\
\hline 8 & $\begin{array}{l}\text { Tabel } \\
\text { cbt_mapel }\end{array}$ & $\begin{array}{l}\text { 'Urut'4 (PK), 'XKodeKelas`4, 'XKodeMapel’3, 'XNamaMapel’, 'XTglBuat’2, 'XPersenUH', } \\
\text { 'XPersenUTS', 'XPersenUAS', 'XKKM', 'XMapelAgama', 'XKodeSekolah`4 }\end{array}$ \\
\hline 9 & Tabel cbt_user & 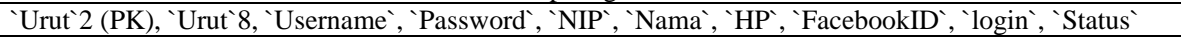 \\
\hline 10 & $\begin{array}{l}\text { Tabel } \\
\text { cbt_kelas }\end{array}$ & $\begin{array}{l}\text { 'Urut' (PK), 'XKodeLevel', 'XNamaKelas', 'XKodeJurusan', 'XKodeKelas', 'XStatusKelas', } \\
\text { 'XKodeSekolah' }\end{array}$ \\
\hline 11 & $\begin{array}{l}\text { Tabel } \\
\text { cbt_tes }\end{array}$ & 'Urut`8 (PK), ‘Urut`7, ‘XKodeUjian`5, ‘XNamaUjian` \\
\hline 12 & $\begin{array}{l}\text { Tabel } \\
\text { cbt_upload_file }\end{array}$ & 'Urut’ (PK), 'XNamaFile’, 'XFolder', 'XKeterangan`, 'XCreated’ \\
\hline 13 & $\begin{array}{l}\text { Tabel } \\
\text { cbt_siswa_ujian }\end{array}$ & $\begin{array}{l}\text { 'Urut'5 (PK), 'XNomerUjian', 'XNISN', 'XKodeKelas', 'XNamaMapel', 'XKodeSoal', 'XPilGanda', } \\
\text { 'XEsai, 'XJumSoal', 'XTglUjian', 'XJamUjian', 'XMulaiUjian', 'XLastUpdate', 'XSisaWaktu', } \\
\text { 'XLamaUjian', 'XTargetUjian', 'XTokenUjian', 'XSelesaiUjian', 'XSetId', 'XKodeUjian', 'XSesi', } \\
\text { 'XStatusUjian', 'XKodeSekolah', 'XGetIP' }\end{array}$ \\
\hline
\end{tabular}

\section{Penerapan Akses Token}

Dalam sistem komputer, akses token berisi kredensial keamanan untuk sesi login dan mengidentifikasi pengguna, grup pengguna, hak istimewa pengguna di dalam beberapa kasus pada aplikasi tertentu. Akses Token adalah objek yang merangkum identitas keamanan suatu proses yang digunakan untuk membuat keputusan keamanan dan untuk menyimpan informasi anti-perusakan tentang beberapa entitas sistem. Akses token umumnya digunakan untuk hanya mewakili informasi keamanan (Nugroho, 2004).

Dengan menggunakan akses token kita dapat mengelompokkan beberapa efek format yang ada pada halaman web, akses token yang digunakan adalah semua kode matematis seperti tanda kurung siku, kurung kurawal dan beberapa token yang berbentuk ungkapan seperti Comment, URL, dan lain sebagainya. Fungsi utama Akses Token yaitu untuk membangkitkan OTP (one-time password) dalam mode challenge / response dan mode response only. Contoh source code token untuk membangkitkan OTP dalam mode response only dapat dilihat pada gambar 7.

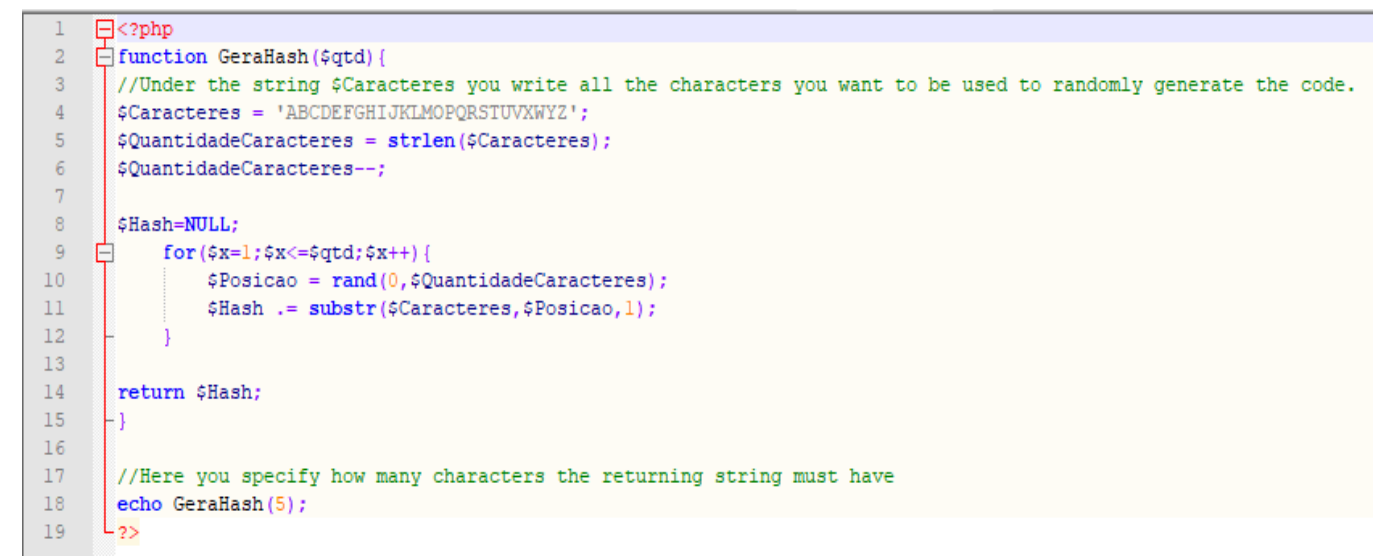

Gambar 7. Source Code Akses Token 
Objek token terbagi menjadi dua jenis, yakni:

1. Primary Token, yakni token yang mengidentifikasikan konteks keamanan dari sebuah proses

2. Impersonation Token, yakni token yang mengadopsi sebuah konteks keamanan yang berbeda (umumnya pengguna lainnya) secara sementara.

\section{Algoritma Simple Random Sampling}

Simple Random Sampling merupakan sampling acak, dimana setiap elemen memiliki peluang yang sama untuk dipilih dari populasi. Pada algoritma Simple Random Sampling dilakukan prosedur sebagai berikut (Kusmana, 2015):

1. Seluruh sampel atau stasiun diberi nomor, selanjutnya menentukan berapa jumlah sampel yang harus diambil

2. Menggunakan tabel bilangan acak atau menggunakan program komputer seperti software excel untuk memilih satu set bilangan acak

Simple random sampling dapat ditentukan apabila pengambilan anggota sampel dari populasi dilakukan secara acak tanpa memperhatikan strata yang ada dalam populasi itu. Cara demikian dilakukan apabila anggota populasi dianggap homogen. Dapat dilihat bahwa teknik simple random sampling dijabarkan sebagaimana gambar 8 berikut ini.

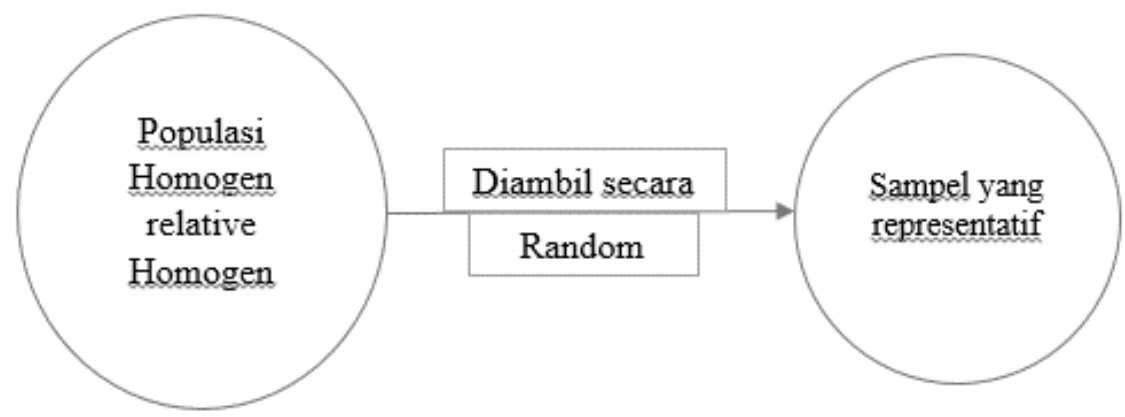

Gambar 8. Teknik Simple Random Sampling

(Sumber : Sugiyono, 2013)

Cochran (1991) mengatakan bahwa definisi Simple Random Sampling adalah sebuah metode untuk memilih $\mathrm{n}$ unit dari $\mathrm{N}$ sehingga setiap elemen dari NCn sampel yang berbeda memepunyai kesempatan yang sama untuk dipilih. Skema simple random sampling dapat terlihat lebih jelasnya seperti gambar 9 di bawah ini. 


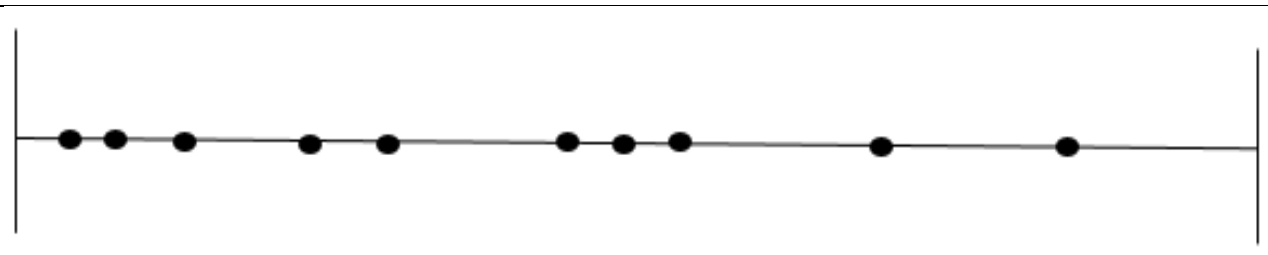

Ssampel dipilih secara acak sejumlah 10 unit $(n=10)$ di sepanjang Garis (Garis tersebut merupakan gambaran populasi yang diamati)

Gambar 9. Skema Simple Random Sampling

(Sumber : Sugiyono, 2013)

\section{Perancangan Antar Muka}

Perancangan antar muka adalah desain untuk komputer, peralatan mesin, perangkat komunikasi mobile, aplikasi perangkat lunak, dan situs web yang berfokus pada pengalaman dan interaksi penggunanya. Tujuan dari penggunaan desain interface ini adalah untuk membuat interaksi pengguna sesederhana mungkin. Bagaimana user berinteraksi dengan komputer menggunakan tampilan antarmuka (interface) yang ada pada layar komputer.

Berikut perancangan antar muka dari beberapa menu utama Aplikasi Ujian Online menggunakan akses token dan algoritman Simple Random Sampling sebagaimana Gambar 10 dan 11 sebagai berikut.

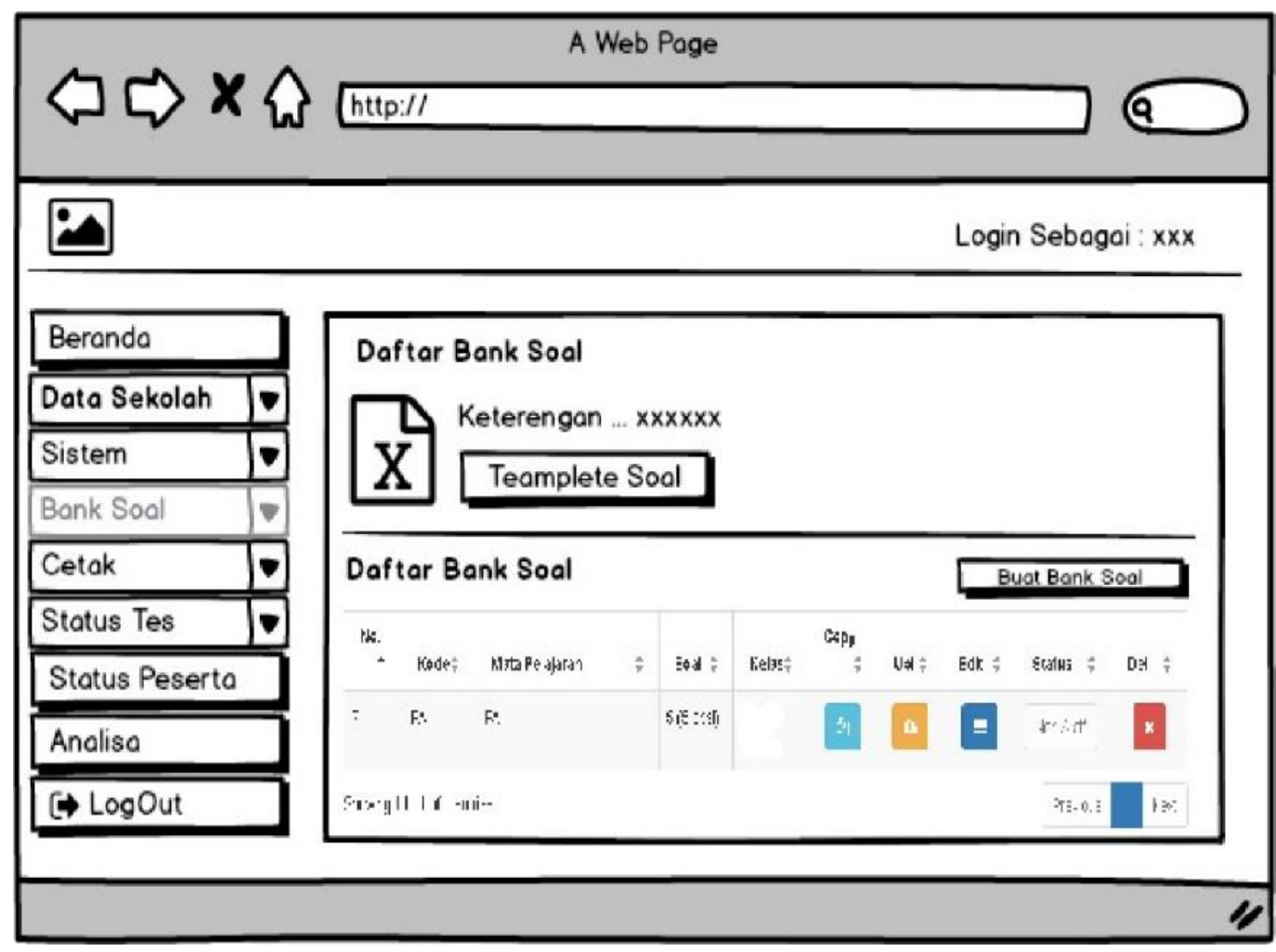

Gambar 10. Desain Tampilan Bank Soal 


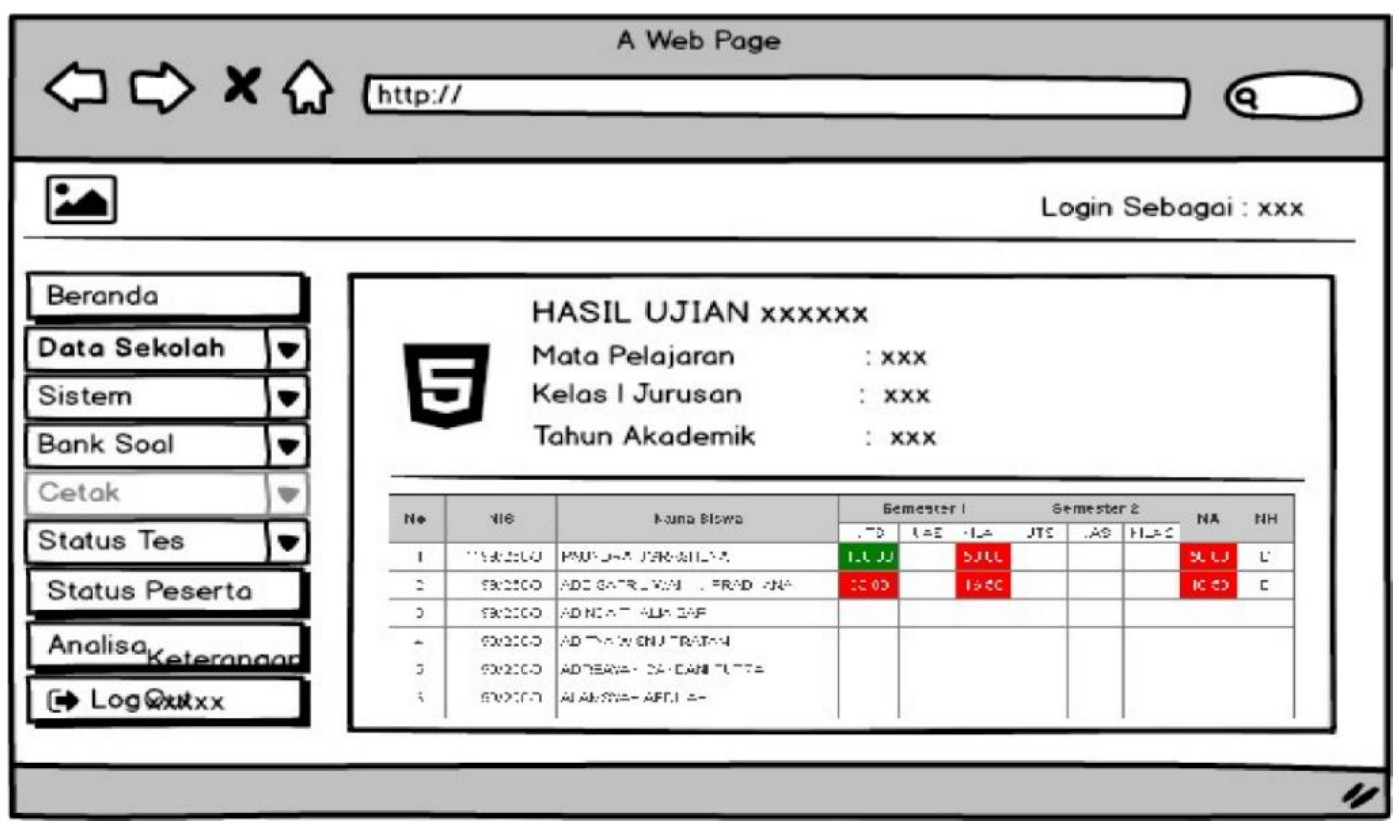

Gambar 11. Desain Tampilan Halaman Ujian

\section{Implementasi Simple Random Sampling}

Algoritma simple random sampling digunakan untuk mengurangi tingkat kecurangan pada saat ujian berlangsung. Dengan sistem random, siswa hanya terfokus pada paket soal yang didapat karena soal berbeda untuk masing-masing siswa. Berikut Gambar 12 implementasi algoritma simple random sampling berupa source code yang digunakan pada Aplikasi ujian online. Formula yang digunakan pada implementasi algoritma simple random sampling dapat dilihat pada Gambar 12 berikut.

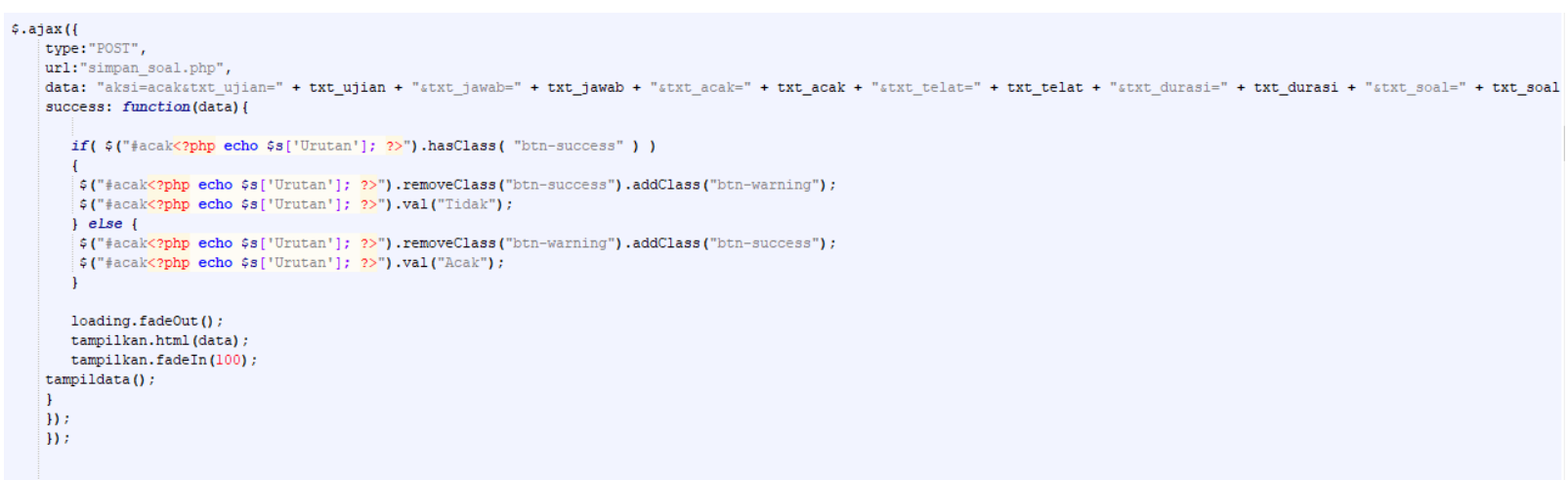

Gambar 12. Implementasi Algoritma Simple Random Sampling

\section{Implementasi Antar Muka}

Berikut Gambar 13 s.d. 15 merupakan merupakan tampilan dari beberapa menu utama di Aplikasi Ujian Online yang telah dibangun. 
SOAL NO.

Ukuran font soal: A A A

Jenis kain strimin pada teknik sulam adalah

(A) Lembut

(B) Meresap

(C) Berlubang

(D) Benvarna

(E) Bertekstur

Gambar 13. Tampilan Menu Ujian Siswa

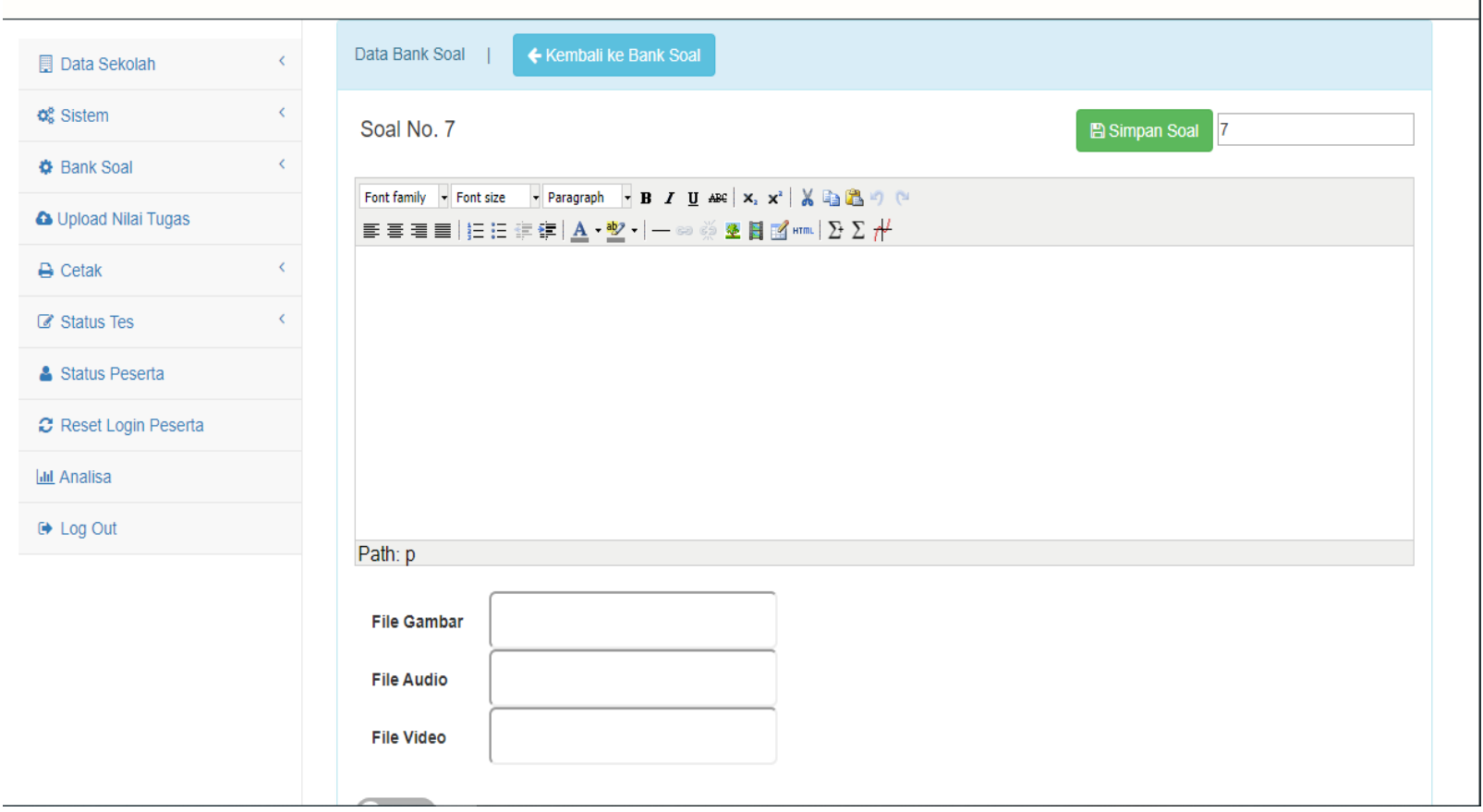

Gambar 14. Tampilan Menu Pembuatan Soal 


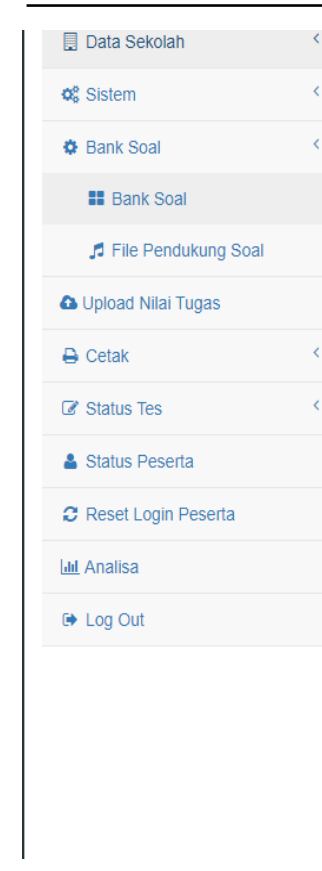

Daftar Bank Soal

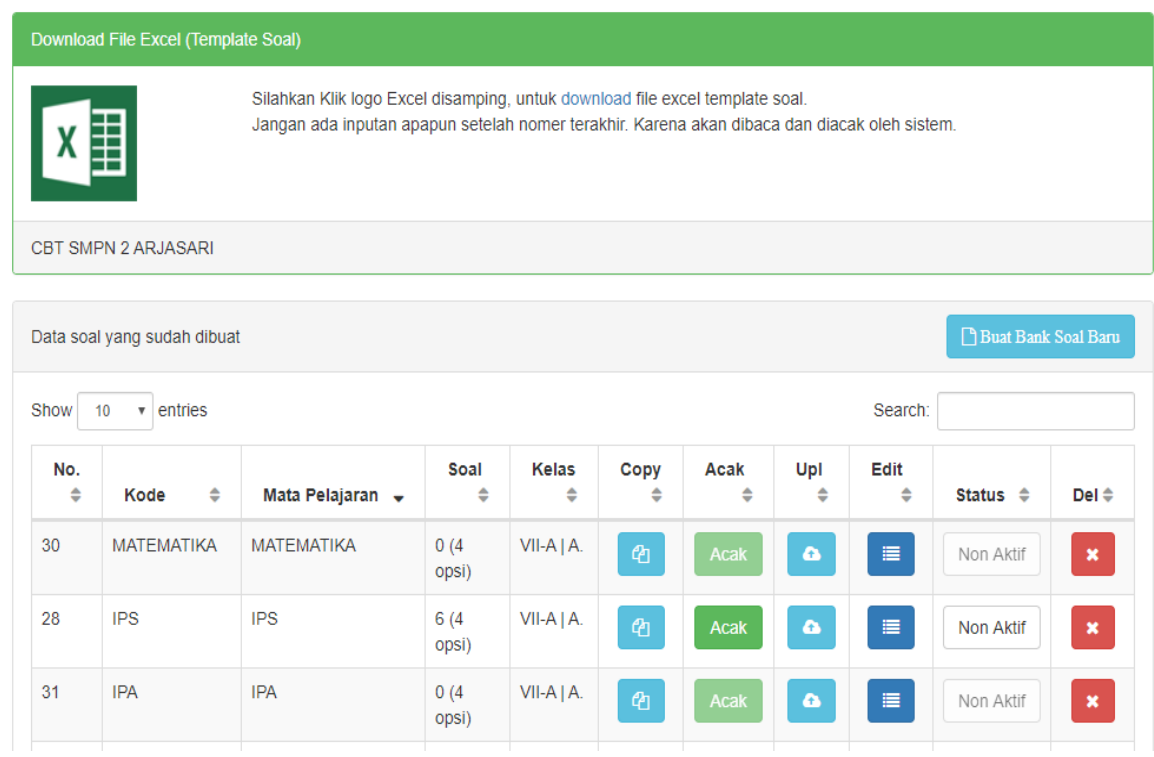

Gambar 15. Tampilan Menu Bank Soal

\section{KESIMPULAN}

Setelah melakukan analisis, pembahasan, perancangan dan pembangunan Aplikasi Ujian Online, maka dapat diambil kesimpulan sebagai berikut :

1. Aplikasi Ujian Online dapat mengatasi permasalahan di sekolah yang dalam hal proses pelaksanaan ujian yang masih menggunakan proses tertulis dan manual baik ujian sekolah maupun ulangan harian bertransformasi menjadi berbasis web dan terkomputerisasi sehingga memudahkan guru maupun siswa dalam proses pembelajaran yang efektif sehingga diharapkan dapat mempengaruhi kualitas belajar siswa.

2. Aplikasi Ujian Online dengan algoritma Simple Random Sampling dilengkapi dengan fitur akses token, acak jawaban, acak soal dan otomatisasi dalam menampilkan nilai ujian pada setiap siswa dapat meminimalisasi kecurangan siswa dalam mengerjakan soal-soal ujian / ulangan.

3. Aplikasi Ujian Online memiliki fitur laporan dan dashboard sebagai bahan evaluasi bagi guru dan siswa dalam proses belajar mengajar.

\section{REKOMENDASI}

Rekomendasi berdasarkan hasil penelitian yang dapat dikembangkan lebih lanjut antara lain : 
1. Integrasi Aplikasi Ujian Online dengan Sistem Informasi Sekolah yang memiliki fungsi pendaftaran siswa dan fungsi keuangan sehingga pada pelaksanaan ujian online, aplikasi hanya memerlukan proses penarikan data secara otomatis dan tidak memerlukan proses upload data siswa.

2. Pengembangan aplikasi berbasis mobile untuk kemudahan akses penggunaan aplikasi yang lebih fleksibel.

\section{REFERENSI}

Amirono, dkk. (2016). Evaluasi \& Penilaian Pembelajaran Kurikulum 2013. Gava Media : Yogyakarta

Awad, Elias M. (1979). System Analysis \& Design, Richard D. Irwin, Homewood, Illinois.

Boehm, B. W. (1988). A Spiral Model of Software Development and Enhancement, Computer, May, 61-72.

Iriana, (2017). Metode Penelitian Terapan, Pa Rama Ilmu : Yogyakarta.

Kemdikbud. (2019). https://unbk.kemdikbud.go.id/\#tentang. Ujian Nasional Berbasis Komputer, diambil pada tanggal 19 Desember 2019

Kusmana, dkk. (2015). Sampling \& Analisis, PT Penerbit IPB Press : Bogor.

Ngalimun. (2017). Evaluasi \& Penilaian Pembelajaran. Pa Rama Ilmu : Yogyakarta

Nugroho. (2004). Cascading Style Sheets (CSS). Gava Media : Yogyakarta

Rusmawan. (2017). Membangun Aplikasi dengan PHP, CodeIgniter \& Ajax. PT Elex Media Komputerindo : Jakarta

Sommerville, Ian. (2014). Software Engineering (Rekayasa Perangkat. Lunak). Jakarta: Erlangga.

Sugiyono. (2013). Cara Mudah Menyusun Skripsi, Tesis \& Disertasi. Penerbit Alfabeta : Bandung.

Sukmadinata, Syaodih. (2003). Landasan Psikologi Proses Pendidikan. Remaja Rosdakarya : Bandung. 